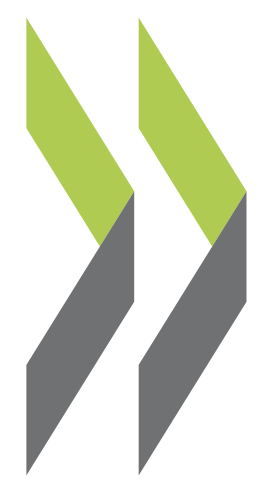

PEB Exchange, Programme on Educational Building 2007/09

\section{School Buildings in Greece:} The Bioclimatic Challenge and a Photovoltaic Pilot

\section{Project}

Panagiotis Al. Patargias,

Kalianou Angela, George Galanis, Marina Vassilopoulou, Maria Drosou, Christos Protogeropoulos https://dx.doi.org/10.1787/075744718437 


\section{School Buildings in Greece: The Bioclimatic Challenge and a Photovoltaic Pilot Project}

By Panagiotis AI. Patargias, University of Peloponnese, SBO; Kalianou Angela, University of Aegean; George Galanis, Marina Vassilopoulou and Maria Drosou, SBO; and Christos Protogeropoulos, CRES, Greece

Greece's School Buildings Organisation (SBO) is developing bioclimatic pilot schemes which are yielding positive results. Bioclimatic action has been one of the principal priorities of Greek school infrastructure planning since 2004. Among the activities undertaken by SBO to use renewable energy sources in school buildings is a pilot project to design and install a photovoltaic system in a secondary school in Athens.

\section{THE BIOCLIMATIC CHALLENGE}

\section{Introduction}

In a constantly changing world, and in a society under almost daily transformation, education is increasingly called upon to play a decisive role. A country's educational infrastructure, which includes teaching, sports and cultural facilities, must create an appropriate environment for education and the transmission of knowledge, while respecting cultural factors and social sensitivities.

Constructing modern, bioclimatic and environmentally friendly school units should be an objective of contemporary societies. The concept of a modern school determines the nature of school infrastructure. Implementing bioclimatic measures and using environmentally friendly materials reflect current trends and should satisfy the following objectives:

- Conserving energy.

- Improving the school's microclimate.

- Producing energy from renewable sources, with the attendant environmental and economic benefits.

- Improving air quality in classrooms.

- Minimising the use of toxic materials.

The need for energy conservation, environmental protection and improved living conditions for the users of school premises has led to implementing the principles of bioclimatic planning in school buildings. In Greece, a large number of old school buildings require bioclimatic conversion. Figure 1 shows the age of school buildings in the Attica region. 


\section{Figure 1 Age of school buildings in the region of Attica}

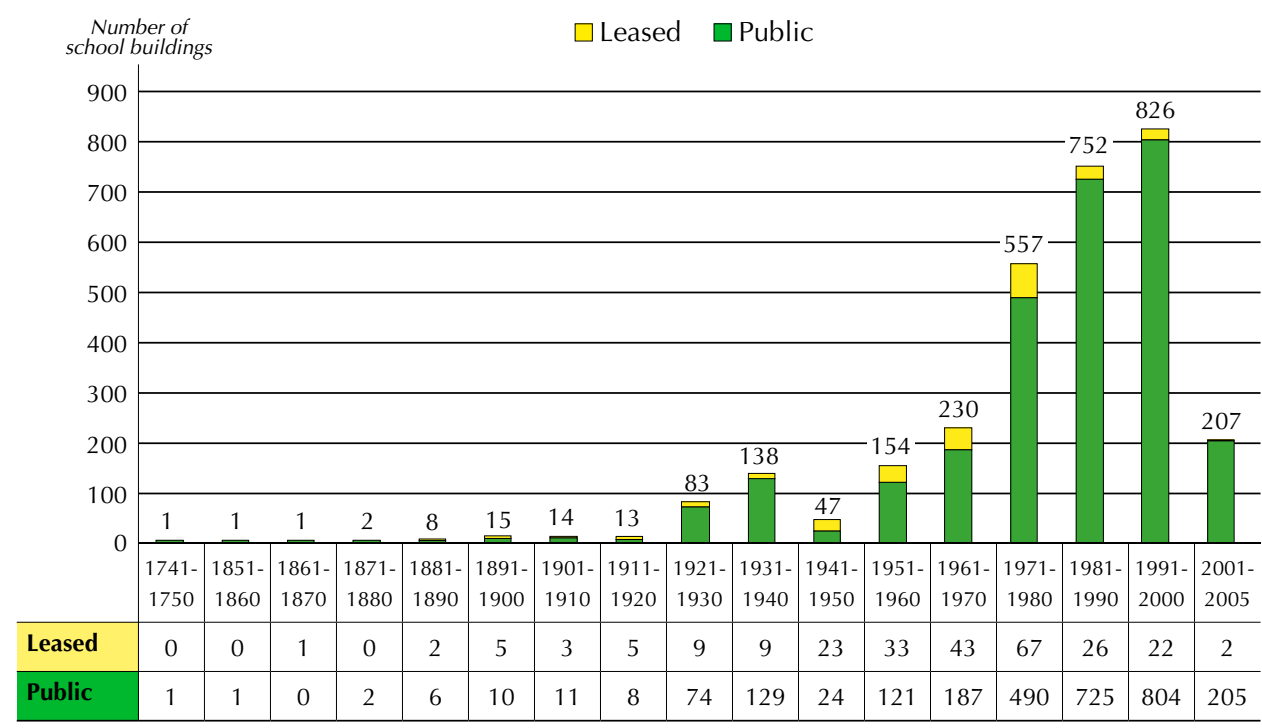

Source: Patargias, P.A. (2005), "Developing and Financing Education through PPPs", paper presented at the Economist Conference "New Investment Opportunities in Greece through Public-Private Partnerships (PPP)", Athens.

The following pilot programmes have already been implemented or are being developed by SBO in co-operation with several universities and distinguished scientists:

1. Photovoltaic systems development (Centre for Renewable Energy Sources).

2. Classroom air quality (Department of Chemistry, Department of Physics, University of Athens).

3. Green roofs (Agricultural University of Athens).

4. Solar heating systems (University of Athens).

5. Smart buildings and light energy conservation.

6. Exterior heat insulation of old school buildings.

7. Energy performance of school buildings (Department of Physics, University of Athens).

8. Shading systems.

9. Schoolyard vegetation.

10. Provision of a mobile pollution measurement unit (Department of Physics, University of Athens).

\section{Generating electricity by photovoltaic systems}

SBO planning provides for photovoltaic systems with a maximum capacity of 20 kilowatts (kw); current construction surveys include such systems where installation is feasible. Preparatory surveys for this innovative measure were conducted jointly by the SBO and the Greek Centre for Renewable Energy Sources, resulting in the installation of a photovoltaic system in the 4th High School of Athens (see case study below), and plans to install such systems in Kamatero Technical Vocational School, Kalamata Music School and the 3rd Primary School of Artemis. The photovoltaic systems are intended to:

- Reduce national energy production from fossil fuels.

- Produce cheaper energy.

- Contribute environmental benefits by reducing gas emissions. 
It is estimated that the cost of constructing a photovoltaic system is recuperable after 10 years; the system's life-span is 25 years.

\section{Improving classroom air quality}

High concentrations of carbon dioxide have a negative impact on the health and performance levels of pupils and teachers. The SBO has therefore installed $\mathrm{CO}_{2}$ sensors in 570 schoolrooms of the Attica region and plans to install them in 500 schoolrooms in the prefecture of Thessaloniki. When $\mathrm{CO}_{2}$ levels surpass the permitted threshold of 1001 parts per million, the sensors activate a ventilation system which renews air in the classroom. Concentrations of $\mathrm{CO}_{2}$ particles and other pollutants (such as carbon monoxide and mono-nitrogen oxides) are reduced simultaneously.

This innovative measure was prepared by three pilot schemes jointly implemented by the SBO with the Departments of Physics and Chemistry of the University of Athens, which indicated classroom levels of $\mathrm{CO}_{2}$ up to $87 \%$ above the permitted level. Table 1 shows the relevant measurements. $\mathrm{CO}_{2}$ sensors have already been included as standard equipment in the construction of new SBO buildings.

\section{Table $1 \mathbf{C O}_{2}$ concentrations in ten Athens schools}

\begin{tabular}{|c|c|c|c|c|}
\hline $\begin{array}{l}\text { School } \\
\text { number }\end{array}$ & $\begin{array}{c}\text { Minimum } \mathrm{CO}_{2} \\
\text { concentration } \\
\text { (parts per million } \\
{[\text { ppm]) }}\end{array}$ & $\begin{array}{c}\text { Mean } \mathrm{CO}_{2} \\
\text { concentration } \\
(\mathrm{ppm})\end{array}$ & $\begin{array}{c}\text { Maximum } \mathrm{CO}_{2} \\
\text { concentration } \\
(\mathrm{ppm})\end{array}$ & $\begin{array}{c}\text { Percentage of } \\
\text { classrooms with } \\
\text { concentrations higher } \\
\text { than the permitted limit } \\
(\%)\end{array}$ \\
\hline 1 & 408 & 600 & 1246 & 38 \\
\hline 2 & 867 & 1258 & 1628 & 100 \\
\hline 3 & 446 & 833 & 1373 & 57 \\
\hline 4 & 367 & 602 & 1040 & 33 \\
\hline 5 & 363 & 576 & 786 & 70 \\
\hline 6 & 105 & 661 & 1133 & 50 \\
\hline 7 & 772 & 1070 & 1873 & 100 \\
\hline 8 & 413 & 675 & 1298 & 50 \\
\hline 9 & 424 & 813 & 1664 & 100 \\
\hline 10 & 396 & 598 & 846 & 45 \\
\hline
\end{tabular}

\section{Further innovative measures}

\section{Green roofs}

A pilot application for a green roof scheme is to be carried out by the SBO in collaboration with the Agricultural University of Athens in Marasleio Primary School, currently up for tender.

\section{Solar heating systems}

The construction of solar heating systems is planned for schools under construction, following the completion of a joint pilot programme by the SBO and the University of Athens.

\section{Smart buildings and light energy conservation}

Seventy percent of school energy consumption is used for heating and $30 \%$ for lighting. A system is currently being researched which can co-evaluate sunlight and the presence of individuals in a room, allowing artificial lighting to be reduced or turned off. Such a system would reduce the light energy consumed by schools by an estimated $40 \%$. 


\section{Other measures}

The SBO is developing a variety of pilot schemes. The exterior heat insulation of old uninsulated schools is the first target, in compliance with the European Union Directive 2002/91/EC ${ }^{1}$ on the energy performance of buildings. The directive is estimated to reduce energy consumption for heating by $30 \%$. Finally, the use of shading systems, high and dense vegetation, and light-reflecting exterior colours will lead to further energy saving by Greek school buildings.

\section{Conclusions}

In view of the threat of further global warming with uncontrollable environmental consequences, the reduction of gas emissions has become an imperative. Energy production is the principal source of gas emissions. Therefore, the way forward is a two-pronged approach: energy conservation and production of energy from renewable sources.

For school buildings, which constitute the largest single class of buildings in a country, energy conservation depends crucially on the following factors:

- Powerful thermal insulation of the building envelope.

- High quality thermal insulation of piping used for heating and air conditioning.

- Passive conservation systems such as shading, high vegetation, ventilation, light-reflecting exterior colours and light-reduction systems in smart buildings.

- Solar heating.

Concerning renewable energy production for Greek schools, the use of photovoltaic systems is the only available option. If comparable efforts are invested in all public buildings, and subsequently in private buildings, even in the form of conversions, we can hope for a cleaner environment and a cleaner planet.

\section{References}

Beisteiner, A. and Coley, D.A. (2003), "Carbon Dioxide Levels and Summertime Ventilation Rates in UK Schools", International Journal of Ventilation, Vol. 1, No. 3, pp. 181-187.

CRES (Centre for Renewable Energy Sources) (2006), "Study of P/S System in the 4th High School in Athens", 2006. Lee S.C. and Chang M. (1999), "Indoor Air Quality - Investigations at Five Classrooms", Indoor Air, Vol. 9, pp. 134138.

Patargias, P.A. (2005), "Developing and Financing Education through PPPs", paper presented at The Economist Conference "New Investment Opportunities in Greece through Public-Private Partnerships (PPP)", Athens.

Santamouris, M., et al. (1994), "Energy Consumption and the Potential for Energy Conservation in School Buildings in Hellas", Energy, Vol. 19, No. 6, pp. 653-660.

SBO (School Buildings Organisation) (2004), "Concentration of Pollutants in the School Orders", SBO/Department of Physics University of Athens pilot programme, Athens.

1. Directive 2002/91/EC of the European Parliament on the energy performance of buildings has been in force since 4 January 2006 and is progressively being incorporated into the national legislation of member states. The European Union has set the target of 20\% renewable energy consumption by 2010. 
Synnefa, A. (2002), "Étude de la qualité de l'air intérieur dans six bâtiments scolaires", DEA thesis, École Nationale des Travaux Publics de l'État, Laboratoire Sciences de l'Habitat.

Synnefa, A. et al. (2003), "An Experimental Investigation of the Indoor Air Quality in Fifteen School Buildings in Athens, Greece", International Journal of Ventilation, Vol. 2, No. 3, pp. 185-202.

For more information, contact the authors:

Panagiotis Al. Patargias

Associate Professor, University of Peloponnese

Managing Director, School Buildings Organisation (SBO)

Athens, Greece

E-mail: admin@osk.gr

Kalianou Angela

Doctoral Candidate, University of Aegean

School of Humanities

Department of Primary Education

\section{INSTALLING A PHOTOVOLTAIC SYSTEM IN AN ATHENS SCHOOL BUILDING}

\section{Introduction}

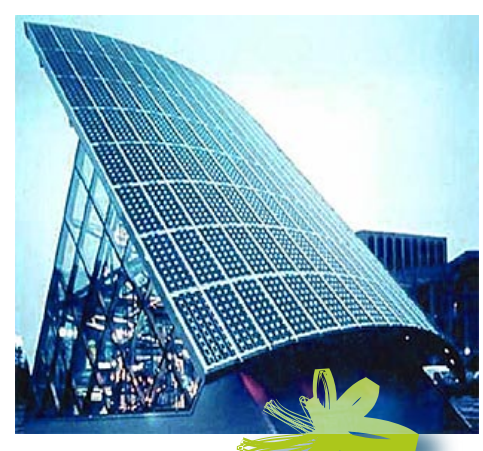

(2)

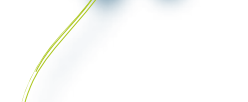

SBO selected the $4^{\text {th }}$ High School of Athens, built in 1982, as a pilot for installing a photovoltaic system for the following reasons:

- The teachers and students had shown a particular interest in the photovoltaic system during the educational environmental programmes in which they participate. Additionally, the teachers expressed willingness to demonstrate and explain the system's features to students, giving the project an educational character.

- As the school is already in operation, all the data concerning its electric energy consumption over the past years are available, and the energy and financial benefits from the photovoltaic system can therefore be easily estimated.

- As the building is located in a central and over-populated area of the city of Athens, it permits studying a system under challenging urban planning and environmental conditions.

For this pilot project, SBO decided to install a photovoltaic system that will be connected to the city's power distribution network and feed into it the electric energy the school will produce. SBO conducted 
the necessary studies in collaboration with the national Centre for Renewable Energy Sources which has significant experience in energy supply and use and its environmental impact.

\section{Photovoltaic technology}

Photovoltaic systems directly convert solar energy into electric energy. A typical photovoltaic system is comprised of (1) a photovoltaic panel or solar generator, (2) an element that manages the electricity produced such as an inverter or a charger, and (3) an energy storage mechanism that consists of batteries and is required when the building's power supply operates as an isolated system (see Figure 2).

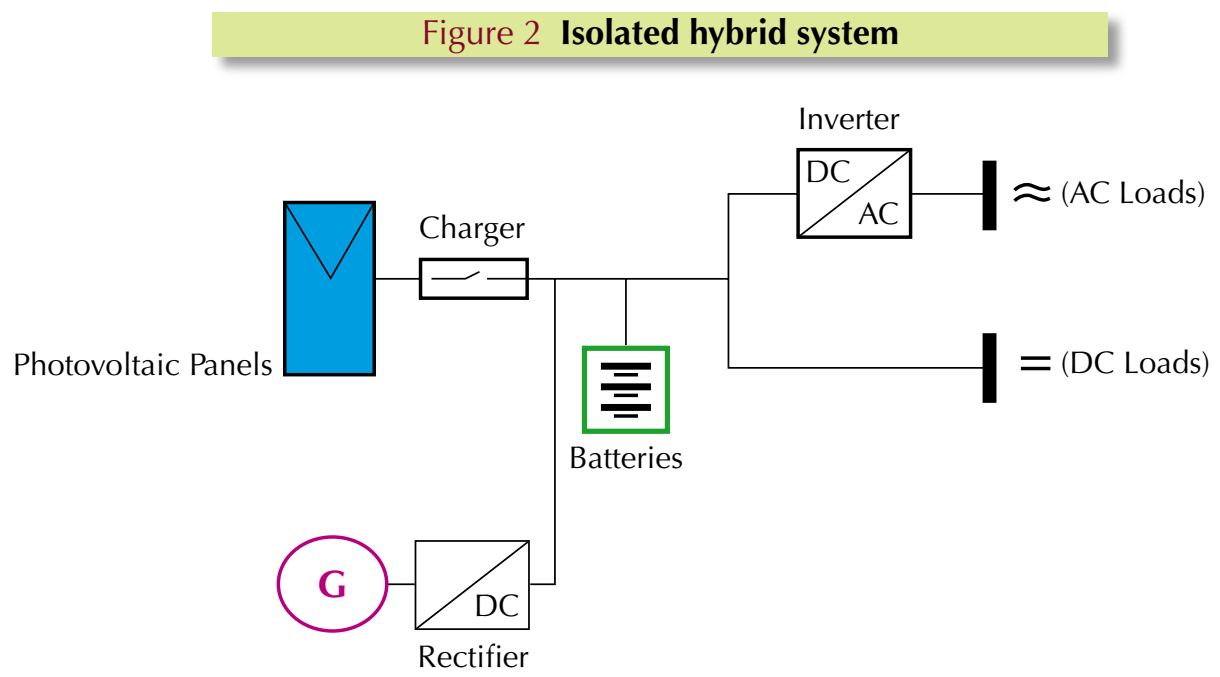

Photovoltaic technology offers the following advantages:

- Negligible environmental impact.

- Production and consumption of electric energy which does not require using power transmission or distribution network facilities.

- Technology that permits increasing the installed capacity according to the load demand.

- Increased reliability of the energy system.

- Minimum requirements for maintaining and overseeing its operation (a periodic inspection is recommended twice a year).

\section{Location of photovoltaic panels}

The school selected for the project is surrounded by tall buildings and located in an area with narrow streets. Therefore, to avoid being shadowed by the adjacent buildings, the photovoltaic panels will be installed on the school's roof which offers a horizontal surface.

Photovoltaic panels are typically placed at an angle in respect to the latitude of the site, which for Athens is $38^{\circ}$. For this particular school building, the panels will be at a $30^{\circ}$ angle (see Figure 3 ) in order to maximise the total annual electric energy production.

As the panels will be placed successively, the minimum distance between them was calculated to ensure that no panel will be shadowed, especially during the winter when the sun is at its lowest. 


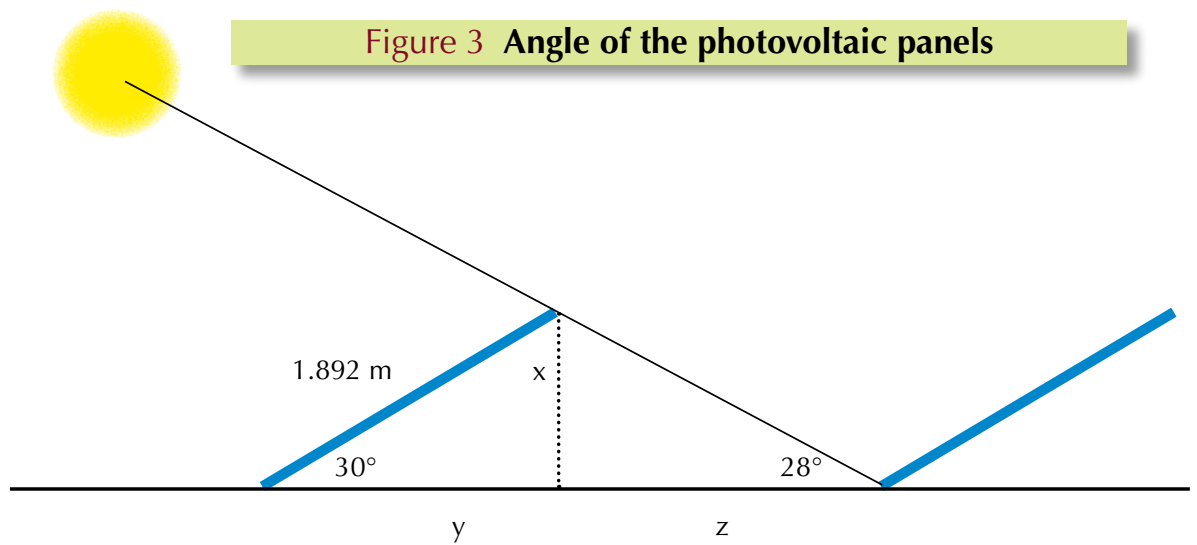

To determine the placement of the photovoltaic panels, a simulation study was performed using data about the school's roof and adjacent buildings and taking into account the possibility of students visiting the facilities (see Figure 4 and photos below).

Figure 4 Roof plan showing photovoltaic panels
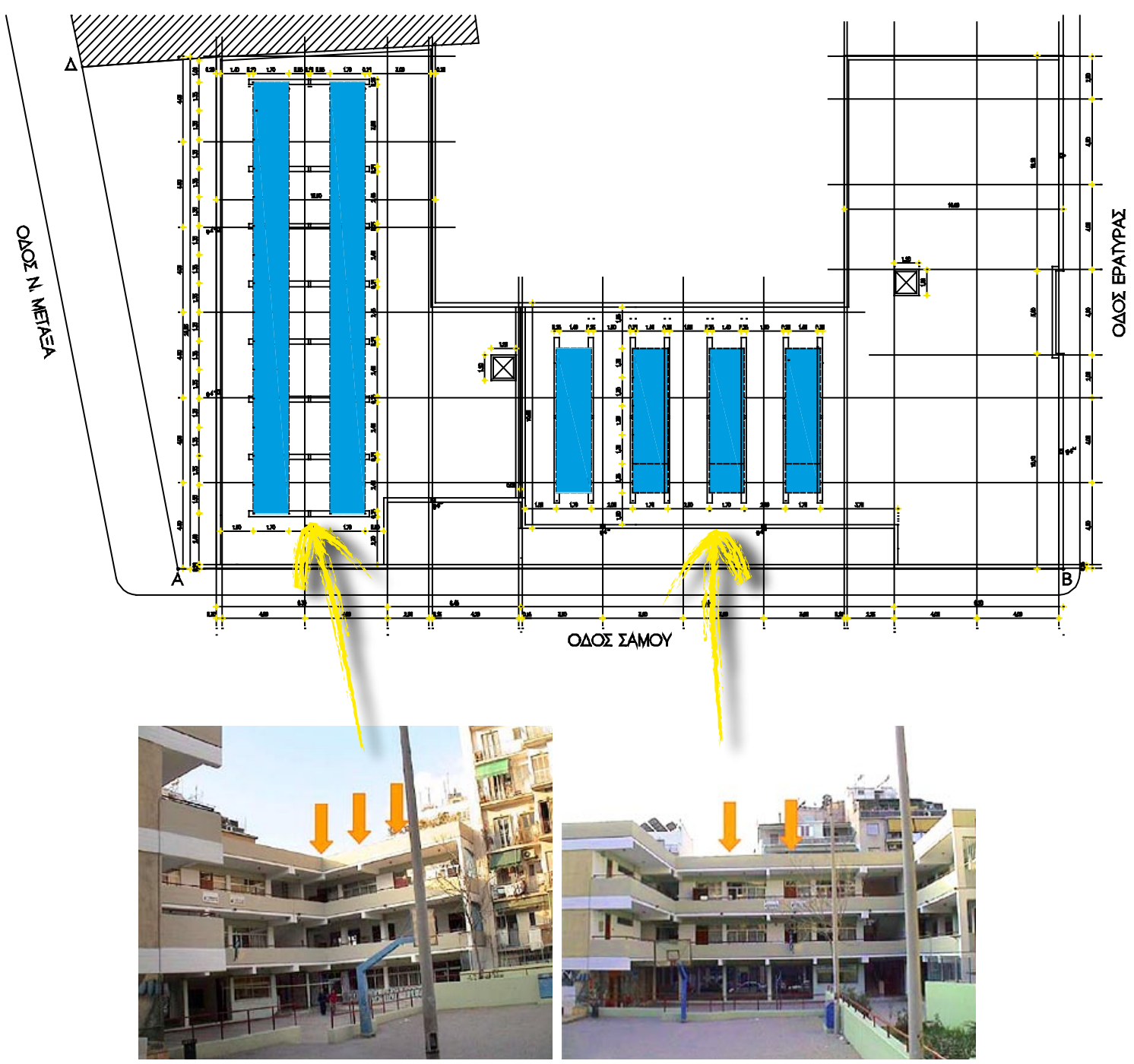
To evaluate the system and calculate the electric energy fed into the distribution network, a computer will collect and record measurements daily. In particular, it will record:

- Global solar radiation on the surface of the photovoltaics panels.

- Ambient temperature.

- Temperature of operation for the photovoltaic panel.

- $\mathrm{AC}$ and DC current.

- $\mathrm{AC}$ and DC voltage.

The photovoltaic system, as mentioned above, will also have an educational character. For this purpose, a special panel with an electronic indicator will be installed centrally in the school and will digitally display the following basic information on the system's operations:

- Instant global solar radiation.

- Power output of the photovoltaic system.

- Total electric energy produced by the photovoltaic system since it was put into operation.

- Fuel savings resulting from the photovoltaic system.

- Reduction of emissions resulting from the photovoltaic system.

\section{Results and benefits}

A simulation for one year of operation showed that the most efficient months from an energy point of view are clearly May to September.

The building's entire photovoltaic system will have a nominal power output equal to $15.75 \mathrm{kWp}$ (peak kilowatts). It will consist of 50 photovoltaic panels of $315 \mathrm{Wp}$ (watts peak) each and five inverters of $3.0 \mathrm{kVA}$ (kilovolt-Ampere) each. The annual electric energy fed into the network from the photovoltaic system is expected reach $22447 \mathrm{kWh}$ based on its total capacity.

In order to calculate the savings of conventional fuels and the corresponding environmental benefits, the electric energy that will be produced is considered to replace the conventional fuels used by the Greek Public Power Corporation at its power stations to produce the same energy values. On an annual basis these are:

- Fuel savings: $6.083 \mathrm{~kg}$.

- Reduction of emissions: $19.711 \mathrm{~kg}$.

All the electric energy produced will be fed into the power distribution network which should earn the school EUR 10000 per year based on current electricity prices. Approximately one third of this amount (EUR 3000 per year) will be used to pay for electric energy to operate the school. The project is expected to be completed in September 2007. Its total cost will be approximately EUR 138000 and its period of depreciation will be about ten years.

The decision to carry out this pilot project was not based soley on the financial benefits, but also on the environmental benefits from the fuel savings and the reduction of gas emissions in a saturated environment. However, the main objective of this project is to demonstrate to the students the use of renewable energy sources, how they work, their efficiency and their effect on the environment. 
Article by:

George Galanis, Civil Engineer

Marina Vassilopoulou, Architect

Maria Drosou, Mechanical Engineer

School Buildings Organisation (SBO)

Athens, Greece

Dr. Christos Protogeropoulos, Mechanical Engineer Centre for Renewable Energy Sources (CRES)

Athens, Greece

For more information contact:

Marina Vassilopoulou

School Buildings Organisation (SBO)

28, Favierou str.

10438 Athens, Greece

Tel.: 302105272540

E-mail: ereyna@osk.gr

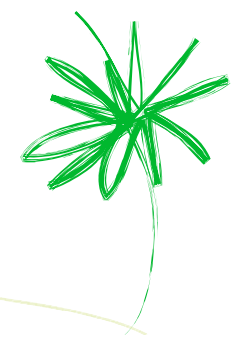




\section{ORGANISATION FOR ECONOMIC CO-OPERATION AND DEVELOPMENT}

The OECD is a unique forum where the governments of 30 democracies work together to address the economic, social and environmental challenges of globalisation. The OECD is also at the forefront of efforts to understand and to help governments respond to new developments and concerns, such as corporate governance, the information economy and the challenges of an ageing population. The Organisation provides a setting where governments can compare policy experiences, seek answers to common problems, identify good practice and work to co-ordinate domestic and international policies.

The OECD member countries are: Australia, Austria, Belgium, Canada, the Czech Republic, Denmark, Finland, France, Germany, Greece, Hungary, Iceland, Ireland, Italy, Japan, Korea, Luxembourg, Mexico, the Netherlands, New Zealand, Norway, Poland, Portugal, the Slovak Republic, Spain, Sweden, Switzerland, Turkey, the United Kingdom and the United States. The Commission of the European Communities takes part in the work of the OECD.

OECD Publishing disseminates widely the results of the Organisation's statistics gathering and research on economic, social and environmental issues, as well as the conventions, guidelines and standards agreed by its members.

This work is published on the responsibility of the Secretary-General of the OECD. The opinions expressed and arguments employed herein do not necessarily reflect the official views of the Organisation or of the governments of its member countries.

No reproduction, copy, transmission or translation of this publication may be made without written permission. Applications should be sent to OECD Publishing rights@oecd.org or by fax 331452499 30. Permission to photocopy a portion of this work should be addressed to the Centre français d'exploitation du droit de copie (CFC), 20, rue des Grands-Augustins, 75006 Paris, France, fax 331463467 19, contact@cfcopies.com or (for US only) to Copyright Clearance Center (CCC), 222 Rosewood Drive Danvers, MA 01923, USA, fax 1978646 8600, info@copyright.com. 